sauté permettant de changer l'orientation du corps) et la gambada ou gamba (l'enjambée). Son passus est l'espace mesuré par chaque enjambée : il repose sur l'esthétique de l'enchaînement avec le rythme, la musique ou l'air chanté ; l'ictus est le point de contact avec le sol et le punctus la marque de la mesure.

Outre sa courte démonstration inaugurale, Ad suos compagnones reste un curieux objet littéraire d'un genre macaronique unique, ressemblant à une farce lexicale avec comme prétexte un récit autobiographique épique et un traité de gestes dansés. Dans ce récit où il se rapporte à divers sujets, Arena semble avant tout l'inventeur de mots et de vers qui suivent la cadence d'une gaillarde. Pour le lecteur qui se prêterait à l'anachronique fantaisie de lire à voix haute le texte original, les vers macaronés d'Arena se mettront à danser à ses oreilles.

ZAVEN PARÉ, Université Libre de Bruxelles

\title{
Bruscambille.
}

Oeuvres complètes. Les Fantaisies. Les nouvelles et plaisantes Imaginations. Facecieuses Paradoxes. Pamphlets.

Critical edition by Hugh Roberts and Annette Tomarken. Textes littéraires de la Renaissance 15. Paris: Honoré Champion, 2012. Pp. 820. ISBN 978-2-74532491-7 (hardcover) €153.75.

This long-awaited edition, by two well-known specialists in the field, will delight all fans of French Renaissance wit (and sometimes, obscenity). A lengthy introduction with five illustrations situates Bruscambille, one of the best-known farceurs $d u$ Pont-Neuf, in his time (early seventeenth century) and among his contemporaries. It also analyzes his use of the paradoxical encomium and of galimatias (nonsense), and discusses his sources at length. A lengthy, and presumably complete, bibliography of Bruscambille's published works precedes the texts.

The first work is Les Fantaisies de Bruscambille. Contenant plusieurs Discours, Paradoxes, Harangues \& Prologues facecieux (1612). Over 200 pages, it deals with a wide variety of subjects, from ugly faces (173), ignorance (184), and the uselessness of science (217, with many Latin phrases), to paradoxical praise of farting $(225,230,233)$ and cuckoldry $(237,240,244,331)$. A 
number of prologues are in galimatias (301-16), which I find less amusing than seventeenth-century readers presumably did.

The next collection is Les Nouvelles et Plaisantes Imaginations de Bruscambille (1613). After a prologue couched in such flowery language that it's hard to follow, we get the usual mishmash of subjects: Pythagoreans, women, matches, Mexico, paper, cowards, medicine, fleas, and beards, among many others. Particularly interesting are the texts on comedy (455) and tragedy (516), and on the Latin word conculcavimus (414), which of course in French consists of four obscene words, as Béroalde de Verville had already explained.

I found most of the Facecieuses Paradoxes de Bruscambille, \& autres discours Comiques (1615) rather boring, whether "En faveur des Tetins d'une Nymphe" (544) or pro-law, winter or pedantry. Two more interesting efforts are on cookery (532; cooking as a demonstration of the four cardinal virtues) and "la felicité Chiatique" (541; defecating as an illustration of bene vivere et laetari).

The Advertissement du Sieur Bruscambille sur le voyage d'Espagne (1615) is very short and deals ostensibly with the journey to Spain of Louis XIII and his sister Elisabeth de Bourbon, but is largely galimatias. Le Discours de Bruscambille, avec la description de Conchini Conchino (1618), even shorter, is an anti-Concini pamphlet, and the Predictions grotesques et recréatives, $d u$ Docteur Bruscambille, Pour l'année 1619 (1618) is an example of the popular spoof predictions of the time.

Next come the Peripatetiques Resolutions et Remonstrances sententieuses du Docteur Bruscambille. Aux perturbateurs de l'Estat (1619), which like most of these texts would be incomprehensible without the editors' notes; Les Bigarures sentencieuses du Docteur Briscambille. Sur le Subject des affaires de ce temps (1622), a plagiarized text which may not be by Bruscambille; and finally the Secrets inestimables, Nouvellement mis au jour par vostre serviteur Deslaurier (1630), a short collection of "secrets," for example, "Secret pour faire peter une servante malgré qu'elle en aye."

I must admit to finding the first two collections both more interesting and more amusing than the rest. Nonsense tends to pall, however much one appreciates the author's ingenuity. But Bruscambille was apparently a polymath who could manipulate the vocabulary of an astonishing variety of subjects including medicine, law, science, and contemporary politics. His Latin is sufficient to be inserted into a discussion of any subject: noses, for instance (180), or lying (247); it can even occupy a sizable proportion of a text, as in the paradoxical 
“defenses" of law (213), ignorance (217), poverty (221), and farting (225, 230, 233).

But even Bruscambille's impressive erudition pales beside that of the editors, without whose copious footnotes many of these pages would be incomprehensible. To take just one example, the "Prologue des habitans de Cornuaille" in Les Fantaisies (244-46) runs to fewer than three pages, has nineteen Latin tags and a total of 23 footnotes. Even if you read Latin, would you know who the "Grammairien de Xaintes" probably was, or what "les Curettes et les Corybantes" are? And here we have only three pages out of a total of 647. In the pages beyond, we find corrections, a very useful glossary, a list of expressions used in the texts, a bibliography, and an index. I have been reading Renaissance literature for 50 years, and yet constantly needed to look at the notes and/or glossary of this volume. Bruscambille represents a seventeenth century very different from that of Molière, Corneille, Racine, and La Fontaine, and the editors are to be heartily congratulated on explaining him to us.

BARBARA C. BOWEN, Vanderbilt University (emerita)

\section{Cicali, Gianni.}

L' Inventio crucis nel teatro rinascimentale fiorentino. Una leggenda tra spettacolo, antisemitismo e propaganda.

Florence: Società Editrice Fiorentina, 2012. Pp. 181. ISBN 978-88-6032-3 (paperback) €15.

Gianni Cicali's engaging L' Inventio crucis nel teatro rinascimentale fiorentino explores the tradition of the Inventio crucis from its earliest beginnings and tracks its development through the fifteenth and sixteenth centuries. In taking on this topic-which is really a study of the "drammaturgia del sacro" as he defines it-Cicali contributes substantively to the legend's scholarship, and does so in a novel manner. Unlike scholars who have examined the issue mainly from the perspectives of history, philology, and art history, Cicali probes the legend's development from the distinctive standpoint of its links to the Medici family, from its anti-Semitic approaches, and from its occasional exotic, oriental leanings. In addition, for the Florentine sacred representations 